\title{
Soteriology on the interface of traditional African religion and Christianity: Engaging Bediako's soteriology and a soteriological alternative
}

\begin{tabular}{|c|c|}
\hline \multicolumn{2}{|c|}{$\begin{array}{l}\text { Authors: } \\
\text { Vhumani Magezi }{ }^{1} \\
\text { Christopher Magezi }^{1}\end{array}$} \\
\hline \multicolumn{2}{|c|}{$\begin{array}{l}\text { Affiliations: } \\
{ }^{1} \text { Faculty of Humanities, } \\
\text { School of Basic Sciences, } \\
\text { North West University, } \\
\text { Vaal Triangle Campus, } \\
\text { South Africa }\end{array}$} \\
\hline \multicolumn{2}{|c|}{$\begin{array}{l}\text { Corresponding author: } \\
\text { Vhumani Magezi, } \\
\text { vhumani@hotmail.com }\end{array}$} \\
\hline \multicolumn{2}{|c|}{$\begin{array}{l}\text { Dates: } \\
\text { Received: } 10 \text { Dec. } 2015 \\
\text { Accepted: } 19 \text { Apr. } 2016 \\
\text { Published: } 18 \text { Aug. } 2016\end{array}$} \\
\hline \multicolumn{2}{|c|}{$\begin{array}{l}\text { How to cite this article: } \\
\text { Magezi, V. \& Magezi, C., } \\
\text { 2016, 'Soteriology on the } \\
\text { interface of traditional } \\
\text { African religion and } \\
\text { Christianity: Engaging } \\
\text { Bediako's soteriology and a } \\
\text { soteriological alternative', In } \\
\text { die Skriflig 50(1), a2068. } \\
\text { http://dx.doi.org/10.4102/ } \\
\text { ids.v50i1.2068 }\end{array}$} \\
\hline \multicolumn{2}{|c|}{$\begin{array}{l}\text { Copyright: } \\
\text { ( 2016. The Authors. } \\
\text { Licensee: AOSIS. This wo } \\
\text { is licensed under the } \\
\text { Creative Commons } \\
\text { Attribution License. }\end{array}$} \\
\hline \multicolumn{2}{|c|}{ Read online: } \\
\hline 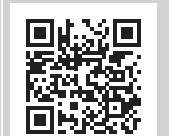 & $\begin{array}{l}\text { Scan this QR } \\
\text { code with your } \\
\text { smart phone or } \\
\text { mobile device } \\
\text { to read online. }\end{array}$ \\
\hline
\end{tabular}

Many African scholars such as Bolaji Idowu, Mbiti, Bediako and others have posed a question about the interrelationship between traditional African religion and Christianity. Some scholars tend to exalt traditional African religion at the expense of the biblical meaning of salvation, as well as undermining the value of traditional African religion. In seeking to establish the interface between traditional African religion and Christianity, this article engages Bediako as one of the most influential African theologians who has thoroughly considered traditional African religion as a preparation for the Gospel. This approach has a danger of misidentifying the unique place of Israel in God's redemptive history, as well as diminishing the biblical meaning of conversion and the newness of the Gospel. Thus, in contrast to Bediako's inclusivism position, the article offers an alternative approach which argues that God's general revelation in all pre-Christian traditional religions is a non-preparation for the Gospel. This is because in Pauline theology ( $\mathrm{Rm}$ 1:18-32), general revelation grants humanity a very limited insight into the divine nature.

\section{Introduction}

Christianity entails shifting belonging and allegiance from one kingdom to the other, namely, from the kingdom of darkness to the kingdom of light. It is about changing from a fallen state of humanity to a new state ushered by a new belonging of 'union' in Christ. This is soteria, commonly called salvation. Soteriology is a pivotal doctrine upon which the Christian salvation doctrine lies. Among African Christians, salvation is identified with the missionary era. The question that has been posed is about the relationship between traditional African religions and Christianity. This question is an emotive one. On the one hand, it borders on diminishing the value of traditional African religion, whilst on the other hand, it challenges one to consider what and how salvation was achieved before missionaries. To address this subject many African scholars (cf. Bediako 1995:82-83; 1999:244-245; Bujo 1992:81; Nyamiti 2006:16) have attempted to draw a relationship between traditional African religious teachings and Christian teachings of salvation in Christ. Whilst this suggests that the subject has been addressed by many African scholars such as John Mbiti, Bolaji Idowu, Kwame Bediako and others, there has been little reflection and engagement with Kwame Bediako (1945-2008) as one of the key theologians who has articulated salvation from its interface with Christianity as taught in the New Testament (Asamoah-Gyadu 2009:9). Considering his post-colonial reading of texts and other emancipatory approaches to the biblical texts, it is imperative to revisit the subject of salvation. In doing so, engaging Bediako ${ }^{1}$ as one of the most influential African theologians and pastors of the late 20th century (Asamoah-Gyadu 2009:5-9; Omenyo 2008:388) would suffice as an enlightening and productive approach.

We regarded Bediako as a representative voice of African theologians because unlike Mbiti's descriptive approach to the question of the interrelationship between traditional African religion and Christianity, the former offers doctrinal concepts which respond to the interface between traditional African religion and Christianity. For example, Bediako (1999:244-245) designated the ancestral category to Christ $^{2}$ by paralleling God's revelation of himself in Jewish culture to African

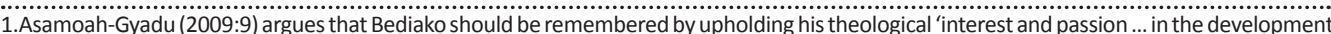
of African Christianity, mother-tongue hermeneutics and the interface between primal religion and Christianity' (Asamoah-Gyadu 2009:9).

2.Bediako's contemporaries like Bujo (1992:79) and Nyamiti (2006:24) also designated the ancestral category to Christ because they view the traditional African ancestors as the forerunners of Christ. In Bujo's view (1992:81), Jesus Christ is 'the ultimate embodiment of all the traditional Afican ancest, the realisation fulfilm fulfilment of African views on ancestorship kinship and its values are found in Christ. The treatment of Christ under the ancestral concept takes the traditional African ancestral world view seriously; however, this approach has encountered serious critiques at both academic and grassroots levels. Scholars who are against the treatment of Christ under the category of ancestor argue that this approach reveals a tendency of diminishing the actuality of Christ as God incarnate and encourages syncretism in African Christianity (Reed \& Mtukwa 2010:144-163; Palmer 2008:65-76 \& Mkole 2000:1138). Concerning the diminishing of Christ as God incarnate, these 
traditional culture. Thus, he justifies the use of a category in which God was at work revealing himself in the same way he used the priestly category of the Jews. This approach is evident in Bediako's (1995) argument that:

\begin{abstract}
... a theology of ancestors is about the interpretation of the past in a way which shows that the present experience and knowledge of the grace of God in the Gospel of Jesus Christ have been truly anticipated and prefigured in the quests and the responses to the Transcendent in former times, as these have been reflected in the lives of African people. (pp. 224-225)
\end{abstract}

Furthermore, we chose Bediako as a representative voice of African theologians because whilst many African scholars tend to react to some early Western missionaries' misrepresentation of the traditional African world views and Christianity in Africa, ${ }^{3}$ Bediako (1994:17) is of the opinion that the '... era of African theological literature as reaction to Western misrepresentation is past'. He understands that: '... what lies ahead is a critical theological construction which will more fully relate the widespread African confidence in the Christian faith to the actual and on-going Christian responses to the life experience of Africans' (Bediako 1994:17).

In consideration of, but moving beyond Bediako's understanding of the interface between the traditional African religions and Christianity, this article seeks to give an alternative approach to the proposed subject. The questions that are posed to guide the discussion are: what is the appropriate and responsible understanding of the meaning of salvation for African Christians? How should one respond to the ideas of Bediako as a representative African theologian regarding the interface between traditional African religion and Christianity and its implications to African Christians?

In order to answer the preceding questions, the researchers will briefly establish Bediako's position on the interface between traditional African religion and Christianity. Related to our study of Bediako concerning the interface between traditional African religion and Christianity, there are three possible theological models or positions which can be adopted. These theological models are pluralism, exclusivism and inclusivism (Ferdinando 2007:124; Kärkkäinen 2003:17-29). The researchers will briefly present all these possible outlooks in order to investigate Bediako's position concerning the three theological models. In doing this, the researchers will

theologians are of the opinion that Christ, since he is God incarnate, transcends the theologians are of the opinion that African ancestor category, which makes Christology. Concerning syncretism, they argue that it is unhelpful to force the preconceived African ancestral category on Christ, since it encourages African Christians to continue to think of Christ in the categories of their natural ancestors. That is, the conceptualisation of Christ in the ancestral concept encourages African Christians to perceive their natural ancestors as intermediaries between themselves and God (Reed \& Mtukwa 2010:157).

3.Bosch (1993:267) acknowledges Mesthene arguing that, because of the Age of Enlightenment, 'the demonic, external power of nature was at last surrendering to human planning and reasoning, thus, enabling humans to remake the world in their own image and according to their own design'. Thus, they dismissed traditional African beliefs by regarding them as merely unscientific, superstitious or irrational (Adewuya 2012:253-254; Haar 2009:45; Imasogie 1983:46-53; Ncozana 2002:147; (Adewuya 2012:253-254; Haar 2009:45; Imasogie 1983:46-53; Ncozana 2002:147;
Salala 1998:137). In doing this, some Western missionaries are believed to have Salala 1998:137). In doing this, some Western missionaries are believed to have that 'the knowledge of God is exclusively based on sensory experience' (Oladipo 2010:42-43, who has based his understanding on Imasogie's work). Given this, 2010:42-43, who has based his understanding on Imasogie's work). Given this, Bosch (1993:291) contends that: '... the scientific and technological
the west at an unparalleled advantage over the rest of the world'.
}

examine whether Bediako's perception of the interface between pre-Christian tradition and Christianity is informed by the broader scope of scripture; or whether he chooses some specific texts to foster his own agenda. Thereafter, the researchers will consider the implications of Bediako's stance (on the interface between traditional African religion and Christianity) for the biblical meaning of salvation. The article will then conclude by bringing the main arguments together.

\section{Bediako's biography}

Kwame Bediako was one of the most influential African theologians and pastors of the late 20th century (AsamoahGyadu 2009:5; Omenyo 2008:388). His death in 2008, at the age of 63 years, was a huge loss for the Church in Africa and beyond (Asamoah-Gyadu 2009:6). Bediako's basic education and his Bachelor of Arts degree were obtained in Ghana (Asamoah-Gyadu 2009:11; Omenyo 2008:387). In the late 1960s, Bediako moved abroad, to the University of Bordeaux to embark on his Masters and Doctoral degrees in French, with particular focus on French African Literature (AsamoahGyadu 2009:11; Omenyo 2008:387). Significantly, whilst in France, Bediako underwent a spectacular conversion experience. Omenyo (2008:387) says that Bediako 'had a dramatic experience with Christ which saw him being converted from atheism to a fervent Christian life'.

After his conversion, Bediako concluded that all academic pursuits which were not rooted in Christ were pointless (Omenyo 2008:387). Asamoah-Gyadu (2009:11) states that Bediako's conversion enabled him to understand the central tenet that: 'Christ is the truth, the integrating principle of life as well as the key to true intellectual coherence, for himself and for the whole world'. Soon after his dramatic conversional experience, Bediako commenced his formal studies in theology at the London School of Theology from 1973 to 1976 (Omenyo 2008:387). He was ordained in 1978 in the Presbyterian Church of Ghana (Omenyo 2008:387). Soon afterwards Bediako left for Aberdeen University in Scotland to complete his doctoral studies in theology under the supervision of Professor Andrew Walls (Asamoah-Gyadu 2009:5; Omenyo 2008:388). After his return to Ghana, he founded and led the Akrofi-Christaller organisation for Mission and Applied Theology ${ }^{19}$ (Asamoah-Gyadu 2009:10; Walls 2008:188).

Bediako wrote many highly rated academic works, and worked at various universities as a visiting lecturer, as well as obtaining various qualifications and appointments at local and international institutions. To mention a few, Bediako was a visiting lecturer at Edinburgh University in Scotland, teaching African Theology (Asamoah-Gyadu 2009:9; Omenyo 2008:388); he was granted an honorary professorship at the University of Kwa-Zulu Natal, as well as an appointment to the fellowship of the Ghana Academy of Arts and Sciences in 1995 as an acknowledgement of his accomplishment in the domain of academic scholarship (Omenyo 2008:388). Omenyo (2008) concludes that: 
Bediako was a widely travelled man, whose expertise was sought by reputable organizations and institutions, both locally and internationally ... He brought his high quality work and knowledge to bear on international networks, agencies and institutions. (p. 388)

\section{The interface between traditional African religion and Christianity: Bediako's perspective}

Bediako (1995:82-83; 1999:244-245) describes traditional African religion as a preparation for the Gospel ${ }^{4}$ by explicitly stating: 'African traditional religion has been a serious preparation for the gospel in Africa and forms major religious substratum for the idiomatic and existential experience of Christianity in African life ${ }^{\prime 5}$ (Bediako 1995:82-83). However, he is not the first African theologian to wrestle with this matter as he acknowledges and supports his predecessors, namely, John Mbiti and Bolaji Idowu (Bediako 1999:267334). These theologians are in concurrence that monotheism, being a belief in both traditional African religions and Christianity, establishes the authenticity of traditional African religion as a preparation for Christianity (Bediako 2000:21). That is, the God of Christianity (who was proclaimed by the early Western missionaries) is the same God who has been worshipped in traditional African religion (Bediako 2000:21). In his discontentment with some early Western missionaries' presentation of the gospel in Africa, Bediako (2000) argues that:

\footnotetext{
... for many years African theologians have refused to accept the negative view of African religion held by Western Missionaries and have shown consistently the continuity of God from the preChristian past into the Christian present. (p. 21)
}

Unfortunately, Bediako did not qualify the nature of the discontinuity and continuity he refers to. Instead, he just agrees with his predecessors, Idowu and Mbiti, by contending that there is continuity and discontinuity between traditional African religion and Christianity (Bediako 2000:21).

In recognising monotheism as the valid point of continuity between traditional African religion and Christianity, Bediako (1999:245) argues that the New Testament provides a solution to the issue of the interface between Christianity and pre-Christian traditions, on the basis of the universality of Christ (his central theological tenet). Based on Paul's speech at Athens (Acts 17:22-31), Bediako (1999) argues that:

It can rightly be said therefore that the apostle who grasped most firmly the significance of Christ for the entire universe, and who strenuously preached Jesus to Jews as the fulfilment of the promises of the Old Testament, proclaimed with equal conviction that Jesus was to Gentiles also the fulfiller of their deepest religious and spiritual aspirations. (p. 245)

4.Bediako's contemporaries also view the traditional African ancestors as the forerunners of Christ. In Bujo's view (1992:81), this implies that Jesus Christ is 'the ultimate they yearned'. Nyamiti (2006:16) argues that the 'ideal and fulfilment of African views on ancestorship kinship and its values are found in Christ'.

5.One may be interested to know the authors' view about the interrelationship between pre-Christian traditions and Christianity. The authors position will be stated in the final section, which engages Bediako's view in light of the biblical meaning of salvation.
In using this biblical passage, Bediako contends that Christ is the fulfillment of the religious aspirations in traditional African religion, as God's general revelation is within preChristian religions as a preparation for the Gospel. Therefore, Bediako establishes a pre-existent aspiration of Christ in preChristian religions. In this way, Christian conversion for Bediako (2000:21) is not an introduction '... to a new God unrelated to the traditions of our past, but to One who brings to fulfillment all the highest religious and cultural aspirations of our heritage'.

It is uncertain whether Bediako (1999:441) is crediting salvation to non-Christian religions, as he also draws a robust parallel between African Christianity and Hellenistic Christianity from the 2nd century. In his own words, Bediako (1999:441) agrees with Justin Martyr and Clement of Alexandria's position by concluding that the: 'Hellenistic Christianity in the second century and the emergent theological self-consciousness of African Christianity in the twentieth century, belong to one and the same story'. However, this is questionable. In Kärkkäinen's (2003:56-62) historical discussion of the interface between Christianity and non-Christian religions, Justin and Clement's $\mathrm{s}^{6}$ position has the risk of crediting salvation to non-Christian religions. However, based on this evidence, one cannot be justified in concluding that Bediako attributes salvation to non-Christian religions. This is because Bediako clarifies that there is no salvation in pre-Christian religions (salvation is only in Christ), as pre-Christian religions only serve as preparation for Christ to its adherents. In view of the above-mentioned discussion, the ensuing sub-sections will briefly present the pluralist, exclusivist and inclusivist outlooks in order to ascertain Bediako's position within these theological models.

\section{Is Bediako a pluralist?}

Race (1983:viii) and Hick (1987:33-34, 1993:140-147) are two of the adherents of the pluralist position. According to Ferdinando (2007:124), Race (1983:72-73), Sennett (2005:309) and Hick's (1987:33) understanding, pluralism is the claim that all religions lead to equal salvation in diverse ways. This is why Hick (1987:33) - who is an advocate of pluralism further explains that pluralism 'is not a radical departure from the diverse and ever-growing Christian tradition'. Instead, it is a 'further development in ways suggested by the discovery of God's presence and saving activity within other streams of human life' (Hick 1987:33). This is because pluralists contend that the cosmic Christ (Colossians 1:17), who is the saviour of all men (1 Timothy 4:10) is perceived in his approaching death as a source of blessing for many people (Hick 1987:33; Mark 10:45). In establishing this, the

6.For a detailed understanding of Justin and Clement's position concerning the interface between Christianity and pre-Christian religions, one should visit Kärkkäinen's (2003:57-62) study of biblical, historical and contemporary perspectives. Kärkkäinen (2003:57-62) observes that both Clement and Justin perceive a compatibility between Greek philosophy and the Gospel. They argue perceive a compatibility botween that, out of God's common grace, human philosophy serves as a vehicle of salvation, as well as the means of achieving salvation in itself (Karkkainen 2003:57-62). That is, based on the belief that all profitable things come from God, Clement and Justin believe that pagan philosophy was given to the Greeks as a stepping stone to the ful knowledge of God, if it is properly used (Kärkkäinen 2003:62). In this way, both Clement and Justin argue for the possibility of the existence of Christians in nonChristian religions. However, Clement and Justin's understanding seems to lack biblical warrant even though they may claim to have it. 
question of salvation to the unevangelised people or those who lived before the incarnation of Christ (either Jews or Gentiles) is not an issue, as every religion is capable of attaining salvation for its adherents.

Christianity claims to be the only true means of salvation, because of the uniqueness of the incarnation of Christ, the eternal Son of God (Barth 1956:346; Race 1983:7). For this reason, Hick (1993:ix) de-constructed the Orthodox Christian doctrine of Christ's incarnation. In order to parallel Christianity with non-Christian religions, Hick (1993:ix) argues that the incarnation of the divine Logos should be understood in a metaphorical sense. That is, 'Jesus embodied the ideal of a human life lived in faithful response to God ... and he accordingly embodied a love which is a human reflection of the divine love' (Hick 1987:21). In this way, Hick denies Jesus' claim (in John 10:30 \& John 14:9) to be of one being with the Father (Hick 1995:53). He argues that these words were put in Jesus' mouth 60 or 70 years after Jesus' death by the scriptural authors, who expressed their ideas which were developed during the expansion of the early Church (Hick 1995:53). However, Hick's serious weakness is his presumptuous claim to know Jesus better than the disciples, who knew him directly.

This category (pluralism) seems to be a modern ${ }^{7}$ or postmodern endeavour, which succumbs to what is acceptable in multicultural society at the expense of the biblical truth of salvation (McGrath 1995:151). In doing this, pluralists credit salvation to non-Christian religions at the expense of the fundamental truth that Christianity is the only religion which offers authentic restoration of man's eternal fellowship with God, based on Christ's life, death and resurrection (John 14:6 \& Acts 4:12). The researchers agree with Demarest (1991:152) that 'other religions and ideologies are not alternative paths to God but to judgment, for Christ is the only way'. That is, 'religious plurality is a global manifestation of sinful humanity's flawed responses to general revelation and that the dogma of religious pluralism is false' (Demarest 1991:152). Hence, in the midst of the current pluralistic society, we call evangelical theologians to an important task of formulating 'adequate evangelical theology of religions' which is 'shaped by the teachings, values and assumptions of the Bible and be faithful to the central confession of the church throughout the centuries' (Netland 2001:313). However, because Bediako understands pre-Christian religion as a preparation for Christ, he does not fit within the pluralism category.

\section{Is Bediako an exclusivist?}

Exclusivism is a position which maintains that salvation 'is found only through an explicit knowledge and confession of Christ' (Ferdinando 2007:124). Although there are three distinct forms of exclusivism, ${ }^{8}$ Morgan (2008:39) argues that

7.Race (1983:71) argues that pluralism "does not exist in Christian history, rather it started existed in the modern period'.

8.Morgan (2008:39) highlighted three identical forms of exclusivism, namely 'church exclusivism, gospel exclusivism and special revelation exclusivism'. These concepts of exclusivis sub-cat differint an differe salvation outside of the Church; Gospel exclusivists present that there is no salvation without hearing the Gospel; and the special revelation exclusivists sustain that ther is no salvation apart from God's special revelation in Christ (Morgan 2008:39). all exclusivists are concerned with the means which God uses in bringing people to the saving knowledge of Christ. A few of the evangelical adherents of this position are Demarest (1991:135-152), Morgan (2008:79-39); Ferdinando (2007:124-135), Barth (1956:309), Calvin (1960:42-68), Strange (2008:72), Edgar (2008:93-95) and Schnabel (2008:99, 121). Peterson (2008:193) argues that all exclusivists refuse the sufficiency of general revelation in bringing people to the saving faith by employing Romans 1:18-23. They argue that in Pauline theology, general revelation is only capable of securing condemnation for both Jews and Gentiles (Peterson 2008:192). In this way, the purpose statement for the epistle of Romans (1:16-17) warrants the exclusivists' view that salvation for both Jews and Gentiles is solely grounded in their faith in Jesus Christ (Peterson 2008:192). In sustaining this, Strange (2008:61-62) argues that all exclusivists agree that 'the universality and depth of sin is pervasive throughout this section of the letter and both Romans 1:18 begins and Romans 3:20' ends with sin. Therefore, exclusivists do not perceive non-Christian religions as a preparation for the Gospel, as 'general revelation is insufficient for salvation both in terms of its mediation and its message' (Strange 2008:72).

In view of Paul's speech at Athens (Acts 17:18-31), exclusivists disagree with Bediako's 'notion of the universal nature and activity of Christ among the heathen' (Ferdinando 2007:125). For example, Ferdinando (2007:124-125), Demarest (1991:139) and Gempf (1993:53) argue that there is none of the continuity or fulfillment which Bediako sees between the Athenian god and the God of Christianity which Paul was preaching to the Athenians. Here, Paul quoted from pagan literature and philosophy in order to demonstrate the mistakes or inconsistencies intrinsic within the Athenians' pagan belief system about God. Therefore, Paul is correcting the Athenians' misconception about God in view of God's self-revelation in Christ. In this way, all exclusivists perceive non-Christian religions as a non-preparation for the Gospel, as they have nothing to do with Christianity. Demarest (1991) summarises the exclusivist position in light of Acts 17 (v. 18, 23), as follows:

$[T]$ he Athenians were caught in huge confusion and error, hence Paul declared against their distorted truth by declaring the personal, wise and sovereign God of heaven and his saving action in the resurrected Jesus Christ. (p. 139)

Schnabel (2008:113) expands Demarest's summary in his prolonged argument that Paul's speech at Athens contradicts the Athenians' belief system. He puts it this way:

Paul here does not regard the Athenians' various systems of faith and worship as less or more identical with or at least similar to, the Christians' convictions concerning God, the world, humankind, history, and salvation. He does not argue for essential continuity between the revelation of the God whom he proclaims and the convictions of pagan poets and philosophers. Instead, he disputes the Athenians' understanding of the divine. (p. 113)

Currently, Strange (2014) presents us with an exclusivism position which makes the exclusivism category complex to comprehend. That is, although Strange (2014:103-273) is an exclusivist according to the standard categorisation, he has 
an optimistic view on the interrelationship between nonChristian traditions and Christianity. Strange (2014:268-273) identifies both continuity and discontinuity ${ }^{9}$ between Christianity and non-Christian traditions like the African traditional religion. In the missional nature of his theology, Strange employed a presupposition that views other religions as borrowing their revelation from the true God; however, the Gospel of Christ stands in opposition to the pervasion of revelation by non-Christian religions. In this way, Christ is seen as actively fulfilling the various elemental aspects of true revelation within pre-Christian religions. This position currently expressed by Strange indicates that the standard exclusivism position is helpful but there is more need for precision as the exclusivism category encompasses internal distinctions.

In-spite of these seemingly internal distinctions in the exclusivism category, one presumes that the exclusivists are correct in disagreeing with Bediako's appropriation of Acts 17 as affirming continuity between the God of traditional African religion and Christianity (Gempf 1993:51-53). Nonetheless, one can go to the extreme of denying that Paul at Athens is using some points of contact to communicate the Gospel to his audiences. In affirming the foregoing statement, one would not be considering the doctrine of general revelation from a broad scriptural perspective. That is to say, one would be failing to understand that general revelation provokes to the heathens a sense of the existence of the creator God (Psalms 92). On the contrary, one should grasp that Paul finds a points of contact with the Athenians, which they conceived from general revelation. Thus, when Paul quoted the Athenians' pagan philosophy (Epicurean and Stoic) and literature (Aretas), he is certainly using its distorted belief system about God in order to create a conversation. This is the conversation which Paul used as a means to rectify the Athenians by pointing them to the actual God, who revealed himself in and through Jesus Christ (Acts 17:16-34). In affirming this, one is neither inclining towards Bediako's understanding of traditional African religion as a preparation for the Gospel, nor claiming that Paul proclaimed the identical God, which the Athenian non-Christians were already improperly worshipping.

\section{Is Bediako an inclusivist?}

Inclusivism is a complex concept to attribute a precise definition to, as it encompasses a 'broad spectrum of opinions' (Pinnock 1995:98). There are two major subcategories of the inclusivist position. Sennett (2005:309-318) and Rahner (1966:116-134) are a few of the major scholars within the inclusivism category. All these theologians are pre-occupied with the question of whether God can use nonChristian religions or general revelation to bring people to salvation (Morgan 2008:38). The first sub-category of inclusivism (its adherents include the Second Vatican Council) is more cautious with the depth of $\sin$, as it does not

9.For interest's sake, Strange $(2014: 103-120)$ sees general and special revelation from Adam to Noah. In view of special revelation, he argues that there was special revelation from Adam to Noah because God communicated directly to humankind. This is an interesting point from Strange, which is worth exploring. view non-Christian religions as the vehicle of Christ's salvation (Pinnock 1995:99). That is, it is aware of the fact that because of the problem of sin, all non-Christian religions are bound to falsehood or wickedness (Pinnock 1995:99). In this way, this category perceives God's general revelation within non-Christian religions as only capable of giving its adherents a perception of God's existence, which neither amounts to their salvation nor to their preparation for the Gospel (Pinnock 1995:99). In other words, the more cautious inclusivism category has a positive view of general revelation, but it maintains that salvation or truth is solely found in people's definitive confession of Jesus Christ. Therefore, one can contend that there is no clear distinction between the more cautious inclusivism and the exclusivism (in subsection 2.2) categories.

Furthermore, Rahner (1966:119-134) and Sennett (2005:313-314) represent less cautious inclusivism, which holds a more positive perception of non-Christian religions. However, Rahner and Sennett's less cautious inclusivism has some internal distinctions. On the one hand, Sennett (2005:313-314) establishes a bare bones inclusivism through his philosophical interpretation of Romans 1:20, which takes a different shape from Rahner's inclusivism. Sennett's bare bones inclusivism argues that God's condemnation of non-Christians, based on general revelation (in Romans 1:20), can only be justified in one way, that is, if non-Christians have the capacity to respond negatively or positively to general revelation (Sennett 2005:314-316). God is not justified in condemning non-Christians on the basis of general revelation, as he predisposes them (non-Christians) to the incapability of responding appropriately to it (general revelation) (Sennett 2005:314-316). Owing to this, Sennett (2005:313) contends that it is coherent for one to philosophically claim that general revelation is capable of bringing salvation to non-Christians without hearing the Gospel, if they respond appropriately to it (general revelation). The opposite is true in that general revelation also brings condemnation if non-Christians respond inappropriately to it (Sennett 2005:313). In doing this, Sennett (2005:314) opens up a possibility of salvation to the unevangelised, including those who lived before the incarnation of Christ. Nevertheless, Sennett's philosophical interpretation of Romans 1:20 is problematic (Peterson 2008:192). This is because he argues for the possibility of unbelievers' appropriate response to general revelation, which Paul did not mention ${ }^{10}$ (Peterson 2008:192).

On the other hand, Rahner (1966:116-134) diverges with Sennett in the sense that he perceives God's general revelation

10.In agreement with Peterson, Romans commentators, like Schreiner (1998:86) and Moo (1996:106) contend that Paul's theology of natural revelation (in Romans) is simply that natural revelation is impossible to bring one to the saving knowledge of God. According to Schreiner (1998:82), in Pauline theology (Romans 1-2:23), both Jews and Gentiles possess the knowledge of God from natural revelation; however, this is the same knowledge they are prone to suppress owing to their inherent Adamic fallen nature. In agreement with Schreiner (1998:86-87), in Pauline Adamic fallen nature. In agreement with Schreiner (1998:86-87), in Pauline theology the rejection of God is concurrent with the knowledge of him, with the result that it is impossible to excavate one's past and find a point in which there was saving knowledge of the true God through natural revelation'. Likewise, Moo (1996:106) understands that Paul, in Romans, affirms the actuality that genera revelation .... in and of itself, leads to a negative result. It is vital if we are to understand Paul's Gospel and his urgency in preaching it to realise that natura revelation leads not to salvation but to the demonstration that God's condemnation is just: people are without excuse'. 
in non-Christian religions as capable of saving them; however, this salvation is still Christ's work through various religious means. This implies that the knowledge of God which humans can reach through the cosmos is already on their (humanity) part a response to a revelation of the Logos, for creation is itself a divine manifestation' (Kärkkäinen 2003:59). This is why Hick (1993:148) writes that Rahner 'recognises the spiritual values of other religions and the occurrence of salvation within them and yet at the same time implicitly affirms the final superiority of his own religion over all others'. In this respect, just like Sennett, Rahner opens up the possibility of having anonymous Christians among the unevangelised, including those who lived before the incarnation of Christ. Race (1983:39) asserts that all inclusivists who hold to Rahner and Sennett's position have an optimistic view of God's operation within non-Christian religions through the interpretation of Acts 14:16-17, Acts 10:35, and Acts 17:22-31. They use Acts 14:17a to argue for the general revelation of the cosmic God in all non-Christian religions, as God did not leave humanity without a witness of himself (Race 1983:39). The common grace and the goodness of God is evident by his provision of rain to everyone in every season (Acts 14:17b) (Race 1983:39). The amplification of this notion climaxed in Acts 17:22-31, in which inclusivists believe that Paul at Athens 'includes the impressive spiritual life of the men of Athens in the Christian way of salvation by conferring a name on the God whom they have already worshipped but did not truly recognise' (Race 1983:39-40). In arguing this, these inclusivists show continuity between non-Christian religions and Christianity.

Given these aforementioned differences within the inclusivism category, Bediako can be classified as a more cautious inclusivist. This is because he perceives nonChristian religions as preparation for the Gospel and recognises that non-Christian religions are incapable of attaining salvation for their followers without their definitive confession of Jesus Christ.

\section{The implications of Bediako's understanding of traditional African religion as a preparation for the gospel}

It is our firm conviction that the concept of salvation is at the heart of scripture (Packer 1990). He puts it this way:

Evangelicals have always seen the question of salvation as one of supreme importance and their witness to the way of salvation as the most precious gift they bring to the rest of the church. This conviction rest not in the memory of conversion of Paul or Augustine or any other evangelical hero, but on the emphasis with which the Bible itself highlights salvation as its central theme. (pp. 111-112)

The above-mentioned emphasis of salvation in scripture arises from the actuality that all human beings are sinful before God (cf. Romans 3:23) because they are marred with the original (or Adam's) sin of Genesis 3. Through Adam's rebellion ( $\sin$ ) before God, all people are in enmity with, and alienation from God (Romans 5). However, scripture confronts humanity with the good news that in the incarnation, death, resurrection and ascension of Christ, God acted from his ontological depth of existence and human existence $^{11}$ in order to save humanity from sin and all its consequences (Torrance 1995:155-156 \& Moltmann 1974:234). That is, out of his eternal love, God assumed our human mode of existence in order to redeem us and reconcile us to God. In this way, salvation or forgiveness of sins comes by God's grace alone through faith in Jesus Christ (cf. Ephesians 2:8-9). Thus, it is the standard evangelical doctrine of salvation we adopt, which states that salvation is passively (not actively) received by faith in Jesus Christ as God's provision for salvation (Tillman 1993:4). Through faith in Christ's redemptive acts, which commence from the incarnation, his life, death and resurrection, all people are confronted by God's unmerited favor of redemption. Thus, we agree with Thimell's (2008:30) affirmation that faith 'does not create a new reality. It simply participates in an already completed event. And even that participation is a sharing in the faithfulness of Jesus'. Thus, in the incarnation, death, resurrection and ascension, God in Christ salved humanity from the pandemic of death and corruption, which they find themselves in as the result of Adam's sin. That is:

$[W]$ ithin this human-inhuman existence of Adam, Jesus Christ comes as the Son of God, the Son of man as Jesus calls himself, to live out a truly obedient and filial, that is a truly human life, in perfect and unbroken union with God the Father ... In all of that Jesus Christ is the last Adam, the one who ... brings to an end the bondage of Adam's sin, breaks its power and opens up a new and living way to God. (Torrance 2008:73)

Biblical salvation is, however, reminiscent of various redemptive aspects. Given this, it is important to mention that Bediako's understanding of traditional African religion as preparation for the Gospel is controversial, as it does not seem to acknowledge the broader perspective of scripture in view of our redemption. This is because it makes one understand conversion from traditional African religion (or any other non-Christian religion) into Christianity as a fulfillment of something which Africans are already partially experiencing in their pre-Christian tradition, or else perceiving conversion as a completion of a pre-Christian religious experience. Indeed, this diminishes both the newness and the transformational (or the counter-cultural) aspect of the Gospel in conjunction with the agented work of the Holy Spirit.

Concerning Christian conversion, the New Testament defines it as 'an act of radical transformation' based on faith in Jesus Christ (Ferdinando 2007:134). Paul, in his epistle of 1 Thessalonians 1:9, demonstrated the exact meaning of conversion as he argued that the Thessalonians 'turned to

11.The doctrine of Christology affirms that Jesus Christ was fully God and fully man (Torrance 2008:232). However, the human nature of Christ does not have its own personal existence/expression (anhypostasis); instead, it found its personal expression in the eternal person of the Divine Logos (enhypostasis) (Torrance 2008:232). The anhypostasis and enhypostasis are two Greek theological terms which are brought together to configure the nature of the person of Christ (read which are brought together to configure the nature of the person of Christ (read the previous reference on Torrance for a detailed understanding of these Greek theological terms). Given this, Moltmann (1974:234) contends that if this divinehuman nature in the person of the eternal Son of God is the centre which create existence, as he suffered and died (on their behalf) for the sake of their redemption. That is, human salvation is not something external to God, but a permanent internal act of God in redeeming humanity from sin and all its consequences 
God from idols to serve the living and true God' (Ferdinando 2007:134). Moreover, Paul set himself as a paradigm of Christian conversion in Philippians 3:7:8, as he argues that his transition into Christianity necessitates the surrender of the heritage and piety which he once treasured' (Ferdinando 2007:134). Once one's conversion to Christianity has occurred, the convert is biblically described as a new creation in Christ (2 Cor 5:17) (Ferdinando 2007:134). Ephesians 2:12-13 indicates the status of Christians prior to their conversion into Christianity as without hope and without God; however, owing to their faith in Christ, they are now reconciled with God (Ferdinando 2007:134). Given this, Bediako's understanding of traditional African religion as preparation for the Gospel tends to confuse the above-outlined biblical meaning of Christian conversion.

Furthermore, Bediako's perception of traditional African religion as a preparation for the Gospel runs the risk of equating non-Judaism religions with Judaism (Ferdinando 2007:133; Sharkey \& Weinandy 2009:172). Here, the contention against Bediako is that God solely reveals himself salvifically in Judaistic religion. This is to say, Judaism is the only religion which God has historically used as a preparation for the Gospel in a salvific sense (Sharkey \& Weinandy 2009:175). Therefore, taking traditional African religion as a preparation for the Gospel seems to be misidentifying the unique place of Israel in God's redemptive history of the world, which found its climax in the salvific incarnation of Jesus Christ. Jesus himself warranted Judaism as the only religion, which holds the special promise of salvation, and serves as preparation for the Gospel (Ferdinando 2007:133; Sharkey \& Weinandy 2009:175). This is evident by Jesus' explanation to his disciples that the Old Testament is an authentic attestation 'of his coming and work' (Luke 24:27) (Ferdinando 2007:133; Mahan 2007:78). Paul made similar remarks in Romans 1:2 (Romans 11:17-25), as he maintained that the Gospel of Christ, which brings salvation to both Jews and Gentiles (through its fulfillment by Jesus Christ), was promised in advance by the Old Testament prophets (Ferdinando 2007:133-134). This indicates that the revelation of God in the Old Testament only prepares the Jews for the Gospel, although they rejected Jesus Christ, who fulfilled their salvific prophetic promises from God (Mark 6:1-6; Matthew 13:54-58).

However, the above discussion does not downplay the significance of general revelation. Instead, it repudiates Bediako's understanding that God's general revelation equals the preparation for the Gospel. In this respect, the researchers hold an exclusivism position (in sub-section 2.2), which argues that in Pauline theology (Romans 1:18-32), general revelation grants humanity a very limited insight into the divine nature. That is, general revelation has nothing about Jesus, as all the general revelation offered to Gentiles is sufficient solely to secure their condemnation by God (Demarest 1991:140-142). This understanding fits well with the whole argument of Romans 1-3, namely that God's will is revealed in natural revelation (Romans 1), and in Jewish law (Romans 2) does not amount to anyone's salvation. Instead, Romans 3 presents the vital truth that all people can only be saved through faith in Jesus Christ. Here, Romans 3:23 is a central verse for the entire argument of Romans 1-3, as Paul unswervingly affirms that 'for all have sinned and fall short of the glory of God'. However, based on Psalm 19 (and other scriptural passages), it is sustained that general revelation cannot amount to anyone's salvation; instead it 'affords all people of all times and places rudimentary knowledge of God as Creator and moral law-giver' (Demarest 1991:151).

\section{Conclusion}

Bediako can be categorised as an inclusivist who views nonChristian religions as a preparation for the Gospel. However, his understanding of traditional African religion as a preparation for the Gospel is controversial. This is because, based on scripture, natural revelation does not amount to anyone's saving knowledge of God nor prepares the Gentiles for their salvation in Christ. Instead, natural revelation arouses the awareness of God's existence to the heathens. Specifically, in Pauline theology, general revelation has the negative result of securing people's condemnation by God. In this way, it is important for one to understand that general revelation within all pre-Christian religions (with the exception of Judaism) does not prepare its adherents for the Gospel. This understanding avoids one's misidentification of the unique place of Israel in God's redemptive history. Also, it will not diminish the biblical meaning of conversion and the newness of the Gospel.

\section{Acknowledgements Competing interests}

The authors declare that they have no financial or personal relationships which may have inappropriately influenced them in writing this article.

\section{Authors' contributions}

V.M. conceptualised the article and its outline, including formulating the core research ideas and theme. C.M. mined the data and conducted preliminary data analysis. Both engaged in the writing, editing, critical reviewing and refining of the article for its completion.

\section{References}

Adewuya, A.J., 2012, 'The spiritual powers of Ephesians 6:10-18 in the light of African Pentecostal spirituality', Bulletin for Biblical Research 22(2), 251-258.

Anon, 2009, 'Bediako, Kwame, 1945-2008', International Bulletin of Mission Research 23(4), 197.

Asamoah-Gyadu, K.J.A., 2009, 'Bediako, Kwame, 1945-2008: Bediako of Africa: A late 20th century outstanding theologian and a teacher', Mission Studies 26(1), 5-16. http://dx.doi.org/10.1163/157338309X442335

Barth, K., 1956, Church dogmatics. The doctrine of the Word of God, vol. 1. 2, transl. G.T. Thomson \& H. Knight, T. \& T. Clark, Edinburgh.

Bediako, K., 1994, 'Understanding African theology in the 20th century', Themelios 20, 14-20.

Bediako, K., 1995, Christianity in Africa: The renewal of a Non-Western Religion, Edinburgh University Press, Edinburgh.

Bediako, K., 1995, 'The significance of modern African Christianity - A manifesto', Studies in World Christianity 1(1), 51-67. http://dx.doi.org/10.3366/swc.1995.1.1.51

Bediako, K., 1999, 'Gospel and culture: Some insights for our time from the experience of the early Church', Journal of African Christian Thought 2(2), 8-12. 
Bediako, K., 2000, Jesus in Africa: The Christian Gospel in African history and experience, Regnum Africa, Yaounde.

Bosch, D.J., 1993, Transforming mission: Paradigm shifts in theology of mission, Orbis Books, Maryknoll, NY.

Bujo, B., 1992, African theology in its social context, Orbis Books, Maryknoll, NY.

Calvin, J., 1960, Institutes of the Christian religion 1, Westminster Press, Philadelphia, PA.

Demarest, B.A., 1991, 'General and special revelation: Epistemological Foundations of religious pluralism', in A.D. Clarke \& B.W. Winter (eds.), One God, One Lord, pp. 135-152, Tyndale House Publishers, Cambridge.

Edgar, W., 2008, 'Exclusivism: Unjust or just', in C.W. Morgan \& R.A. Peterson (eds.) A response to inclusivism: Faith comes by hearing, pp. 78-97, IVP Academic, Downers Grove, IL.

Ferdinando, K., 2007, 'Christian identity in the Africa context: Reflection in Kwame Bediako's theology and identity', Journal of the Evangelical Theological Society 50(1), 121-143.

Gempf, C., 1993, 'Athens, Paul at', in G.F. Hawthorne (ed.), Dictionary of Paul and his letters, pp. 51-54, InterVarsity, Downers Grove, IL.

Haar, G.T., 2009, How God became African: African spirituality and Western secular thought, Philadelphia of Pennsylvania Press, Philadelphia, PA.

Hick, J., 1987, The myth of Christian uniqueness, SCM Press Ltd, Maryknoll, NY.

Hick, J., 1993, The metaphor of God incarnate, SCM Press Ltd, London.

Hick, J., 1995, 'A Pluralistic view', in S.N. Gundry, D.N. Okholm \& R.T. Phillips (eds.), Four views on salvation in a Pluralistic world, pp. 29-59, Zondervan, Grand Rapids, MI.

Imasogie, O., 1983, Guidelines for Christian theology in Africa, Africa Christian Press, Achimota.

Kärkkäinen, V.M., 2003, Biblical, historical and contemporary perspectives: An introduction to the theology of religions, InterVarsity, Downers Grove, IL.

Kruse, C.G., 2012, Paul's letter to the Romans, William B. Eerdmans, Grand Rapids, MI.

Mahan, H., 2007, Bible Class commentaries on John, Romans, 1 \& 2 Corinthians, Grace Books, Danville, CA.

McGrath, A.E., 1995, 'A Particularist view: A post-enlightenment approach', in S.N. Gundry, D.N. Okholm \& R.T. Phillips (eds.), Four views on salvation in a Pluralistic world, pp. 151-180, Zondervan, Grand Rapids, MI.

Mkole, J.C.L., 2000, 'Mark 14:62: Substantial compendium of New Testament Christology', HTS 56(4), 1119-1145.

Moltmann, J., 1974, The crucified God, SCM Press Ltd, London.

Moo, D., 1996, The epistle to the Romans: The new international commentary in the New Testament, William B. Eerdmans Publishers, Grand Rapids, MI.

Morgan, C.W., 2008, 'Incusivisms and exclusivisms', in C.W. Morgan \& R.A. Peterson (eds.), A response to inclusivism: Faith comes by hearing, pp. 17-39, IVP Academic, Downers Grove, IL.

Ncozana, S.S., 2002, The spirit dimension in African Christianity: A pastoral study among the Tumbuka people of northern Malawi, Christian Literature Association Blantyre.

Netland, H., 2001, Encountering Religious Pluralism: The challenge to Christian faith and mission, InterVarsity, Downers Grove, IL.

Nyamiti, C., 2006, Studies in African Christian Theology, Vol 2. Jesus Christ, the Ancestor of Humankind: An essay on African Christianity, CUEA Publishers, Nairobi.
Okholm, D.L. \& Phillips, T.R., 1995, 'Introduction', in S.N. Gundry, D.N. Okholm \& R.T. Phillips (eds.), Four views on salvation in a Pluralistic world, pp. 7-26, Zondervan, Grand Rapids, MI.

Oladipo, C., 2010, 'African Christendom in the twenty first century', Ogbomoso Journal of Theology 15(2), 33-71.

Omenyo, C., 2008, 'Bediako Kwame, 1945-2008', Exchange 37(4), 387-389. http:// dx.doi.org/10.1163/157254308X355372

Packer, J.I., 1990, 'Evangelicals and the way of salvation', in K.S. Kantzer \& C.F.H. Henry (eds.), Evangelical affirmations, pp. 111-112, Zondervan, Grand Rapids, MI.

Palmer, T., 2008, 'Jesus Christ: Our ancestor?', Africa Journal of Evangelical Theology 27(1), 65-76.

Peterson, R., 2008, 'Incusivism versus Exclusivism on key Biblical texts', in C.W. Morgan \& R.A. Peterson (eds.), A response to inclusivism: Faith comes by hearing, pp. 184-200, IVP Academic, Downers Grove, IL.

Peterson, R., 2008, 'Introduction', in C.W. Morgan \& R.A. Peterson (eds.), A response to inclusivism: Faith comes by hearing, pp. 11-16, IVP Academic, Downers Grove, IL.

Pinnock, C.H., 1995, 'An inclusivist view', in S.N. Gundry, D.N. Okholm \& R.T. Phillips (eds.), Four views on salvation in a Pluralistic world, pp. 95-123, Zondervan, Grand Rapids, MI

Race, A., 1983, Christians and religious pluralism: Patterns in the Christian theology of religions, Orbis Books, Maryknoll, NY.

Rahner, K., 1966, Theological investigations, vol. V, transl. K.H. Kruger, Seabury Press, New York.

Reed, R. \& Mtukwa, G., 2010, 'Christ our ancestor: African Christology and the danger of contextualization', Wesleyan Theological Journal 45(1), 144-163.

Salala, C., 1998, 'The world of the Spirits: Basukuma traditional religion and Biblical Christianity', in S. Ngewa, M. Shaw \& T. Tienou (eds.), Issues in African theology, pp. 133-138, East African Education Publishers, Nairobi.

Schnabel, E.J., 2008, 'Other religions: Saving or secular?', in C.W. Morgan \& R.A Peterson (eds.), A response to inclusivism: Faith comes by hearing, pp. 98-122, IVP Academic, Downers Grove, IL.

Schreiner, T., 1998, Romans: Baker exegetical commentary in the New Testament, Baker Academic, Grand Rapids, MI.

Sennett, J.F., 2005, 'Bare bones inclusivsim and the implications of Romans 1:20', Evangelical Quarterly 77(4), 309-319.

Sharkey, M. \& Weinandy, T., 2009, Texts and documents, 1986-2007, Ignatius Press, San Francisco, CA.

Strange, D., 2008, 'General revelation: Sufficient or insufficient', in C.W. Morgan \& R.A Peterson (eds.), A response to inclusivism: Faith comes by hearing, pp. 40-77, IVP Academic, Downers Grove, IL.

Strange, D., 2014, Their rock is not like our rock: A theology of religions, Zondervan, Grand Rapids, MI.

Thimell, D., 2008, 'Torrance's Doctrine of Faith', Princeton Theological Seminary 39(2), 27-34.

Tillman, W.M., 1993, 'The doctrine of salvation', South Western Journal of theology 35(2), 4-31.

Torrance, T.F., 1995, The Trinitarian Faith, T \& T Clark, Edinburgh.

Torrance, T.F., 2008, in R.T. Walker (ed.), Incarnation: The person and life of Christ, IVP Academic, Downers Grove, IL.

Walls, A., 2008, 'Bediako, Kwame, 1945-2008', International Bulletin of Mission Research 32(4), 188-190. http://dx.doi.org/10.1177/239693930803200405 